\title{
ANALISIS KESALAHAN PENGGUNAAN DEIKSIS DALAM KARANGAN SEDERHANA BAHASA JERMAN
}

\author{
Yusuf Tonapa ${ }^{1}$, Muhammad Anwar ${ }^{2}$, dan Mantasiah R. ${ }^{3}$ \\ Program Studi Pendidikan Bahasa Jerman \\ Fakultas Bahasa dan Sastra Universitas Negeri Makassar \\ Email: yusuftnp@gmail.com ${ }^{1}$
}

\begin{abstract}
ABSTRAK
Penelitian ini bertujuan untuk memperoleh data dan informasi tentang kesalahan penggunaan deiksis dalam karangan sederhana bahasa Jerman. Jenis penelitian ini adalah deskriptif kualitatif. Data dikumpulkan melalui tes menulis karangan sederhana dalam bahasa Jerman. Data yang telah diperoleh diidentifikasi dan diklasifikasi jenis kesalahannya; ditentukan tingkat kesalahannya dengan teknik persentase; menjelaskan kesalahan; memprakirakan daerah rawan kesalahan; serta mengoreksi kesalahan. Dari hasil analisis data diketahui bahwa kesalahan penggunaan deiksis persona, yang terdiri atas kesalahan penggunaan Personalpronomen dan Possesivepronomen masing-masing dengan kasus Nominativ dan Akkusativ, sebanyak 97 kesalahan (84,35\%) dengan kategori tinggi sekali; kesalahan penggunaan deiksis temporal sebanyak 3 kesalahan dengan persentase 2,61\% kategori hampir tidak ada kesalahan; dan kesalahan penggunaan deiksis lokasional berjumlah 15 kesalahan $(13,04 \%)$ dengan kategori kurang sekali. Frekuensi kesalahan deiksis persona dalam karangan sederhana bahasa Jerman siswa lebih dominan dibandingkan dengan deiksis temporal dan lokasional.
\end{abstract}

Kata kunci: Deiksis, Karangan Sederhana, Bahasa Jerman

\begin{abstract}
This study aims to obtain data and information about errors in the use of deixis in a simple essay of German. The type of this research is descriptive qualitative. Data were collected through a simple essay writing test in German. The data obtained has been identified and classified the type of error; determined the degree of error with the percentage technique; explain the error; forecast error-prone areas; as well as correcting errors. From the result of data analysis, it is known that errors in the use of personal dexterity, consisting of misappropriation of Personalpronomen and Possesivepronomen respectively with Nominativ and Akkusativ cases, 97 mistakes (84.35\%) with very high category; errors of temporal deixis use of 3 errors with percentage $2.61 \%$ category almost no errors; and errors in the use of locational deixis amounted to 15 errors $(13.04 \%)$ with less category once. The frequency of personic dexterity errors in the German student's simple essay is more dominant than the temporal and locational deixis.
\end{abstract}

Keywords: Deixis. Simple Essay and German Language 


\section{PENDAHULUAN}

Bahasa berfungsi sebagai pengikat masyarakat, karena bahasa merupakan media untuk menghubungkan satu manusia dengan manusia lainnya. Selain itu, bahasa juga merupakan alat dan cara berpikir manusia. Oleh karena itu, bahasa menjadi sangat penting di antara unsur-unsur pelengkap hidup manusia seperti unsur kebudayaan, ilmu pengetahuan, dan teknologi.

Pentingnya bahasa sebagai alat untuk berkomunikasi tidak hanya pada bahasa ibu tetapi juga bahasa asing. Dengan adanya bahasa asing, pengetahuan-pengetahuan dari satu negara ke negara yang lain bisa tersalurkan hingga bisa diketahui oleh manusia. Dengan demikian, wawasan umum manusia dapat meningkat menjadi manusia yang lebih cerdas dalam menghadapi globalisasi.

Selain bahasa Inggris, salah satu bahasa asing yang cukup berpengaruh di benua Eropa adalah bahasa Jerman. Bahasa ini juga memiliki peranan penting di bidang ekonomi global maupun ilmu pengetahuan. Pada dasarnya pembelajaran bahasa Jerman merupakan pembelajaran keterampilan berbahasa. Dari keempat aspek tersebut, aspek menulis memegang peranan penting dalam pengajaran bahasa. Dikatakan penting, karena melalui kegiatan menulis, seseorang dapat menuangkan hasil pemikirannya berupa ide atau bahkan pengetahuan dalam berbagai disiplin ilmu.

Berdasarkan Permendiknas Nomor 22 Tahun 2006 tentang Standar Isi dan Permendiknas Nomor 23 tahun 2006 tentang Standar Kompetensi Lulusan dalam KTSP tahun 2006, maka pembelajaran bahasa Jerman di Sekolah Menengah Atas dan Madrasah Aliyah seharusnya terlaksana dengan baik. Pembelajaran bahasa Jerman dalam keterampilan menulis menuntut siswa untuk menulis kata, frasa, dan kalimat dengan huruf, ejaan, dan tanda baca yang tepat serta mampu mengungkapkan segala ide, pikiran, dan gagasannya secara tertulis dalam bentuk paparan, dialog, atau wacana sederhana terkait tema yang sedang dipelajari.

Siswa harus mampu menguasai dasar-dasar bahasa Jerman terlebih dahulu, agar dapat menulis suatu karangan dalam bentuk wacana sederhana dengan baik. Selain itu juga, diperlukan berbagi metode pembelajaran dalam meningkatkan keterampilan menulis siswa (Mantasiah, 2017; Qalbi, 2017; Romadloni, 2017; Yusri, 2018). Salah satu hal yang paling mendasar di dalam pengajaran suatu bahasa secara khusus bahasa Jerman adalah kata ganti diri (Pronomen), tempat (Lokale Angaben) dan waktu terjadinya peristiwa (Temporale Angaben) yang seluruhnya merupakan bagian dari penggunaan deiksis.

Penguasaan deiksis merupakan salah satu aspek dalam bahasa Jerman yang memengaruhi penulisan seseorang terhadap penulisan suatu karangan sederhana. Tanpa penguasaan deiksis yang cukup, maka sangat besar kemungkinan penulis sulit menuangkan hasil pemikirannya, begitu pula memahami isi suatu bacaan. Disadari akan pentingnya penggunaan deiksis dalam menulis suatu karangan sederhana maka, aspek penguasaan deiksis khususnya dalam bahasa Jerman seharusnya dikuasai oleh seseorang yang mempelajari bahasa Jerman.

Berdasarkan pengalaman penulis sebagai guru PPL II di SMA Negeri 16 Makassar dan hasil wawancara langsung dengan guru bahasa Jerman di SMA Negeri 1 Rindingallo, ditemukan bahwa dari 25 
siswa masih ada sekitar 15 siswa yang belum mampu menguasai penggunaan deiksis secara baik dan benar. Seringkali siswa masih kesulitan dalam mempelajari deiksis khususnya materi Personalpronomen, Lokale Angabe, dan Temporale Angabe. Hal ini disebabkan karena banyaknya perbedaan tata bahasa Jerman dengan bahasa Indonesia baik pada jenis, fungsi maupun penggunaannya. Hal ini yang mengakibatkan sebagian siswa mengalami kesulitan dalam mempelajari bahasa Jerman sehingga terjadi kesalahan dalam membuat suatu karangan.

Beberapa penelitian sebelumnya mengenai penggunaan deiksis di antaranya yang dilakukan oleh Kasebae (2013) yang menyatakan bahwa masing-masing bahasa memiliki penggunaan deiksis yang berbedabeda. Kasebae (2013) menggunakan bahasa Inggris dan bahasa Banggai (Sulawesi Tengah) untuk membandingkan sistem penggunaan deiksis kedua bahasa tersebut. Sejalan dengan Kasebae, penelitian yang dilakukan oleh Syamsurizal (2015) menyatakan bahwa di dalam penggunaan deiksis bahasa Pekal (Bengkulu Utara) terdapat beberapa bentuk yang berbeda pada persona tertentu dan adanya leksem kata yang deiktis, baik leksem verba maupun leksem bukan verba. Selain itu, berdasarkan penelitian yang dilakukan oleh Afifah dan Widodo (2015) pada mahasiswa Universitas Negeri Malang, ditemukan adanya faktorfaktor yang menyebabkan terjadinya kesalahan-kesalahan berbahasa dalam menulis karangan bahasa Jerman, salah satunya adalah elemen pembelajaran bahasa asing.

\section{METODE PENELITIAN}

Dalam penelitian ini digunakan variable tunggal, yaitu kesalahan berbahasa dalam menulis karangan bahasa Jerman. Desain yang digunakan adalah metode deskiptif kualitatif, yaitu menggambarkan secara deskriptif trekait objek penelitian (Jufri, 2007; Jufri, 2017) dalam hal ini adalah jenis-jenis kesalahan yang dilakukan siswa dalam menggunakan deiksis persona (baik Personalpronomen kasus Nominativ dan Akkusatif, maupun Possesivepronomen bentuk Nominativ dan Akkusativ), deiksis waktu, dan deiksis ruang/tempat dalam bahasa Jerman.

Data penelitian ini adalah kalimatkalimat yang dirangkai menjadi karangan sederhana yang ditulis oleh siswa dengan menggunakan deiksis persona Personalpronomen dan Possesivpronomen masing-masing dengan kasus Nominativ dan Akkusativ; deiksis waktu; dan deiksis tempat. Populasi penelitian adalah seluruh siswa kelas XI SMAN 1 Rindingallo yang terdiri dari 7 kelas dengan jumlah siswa 182 siswa. Sumber data penelitian ini adalah seluruh peserta didik kelas XI IPA 2 SMA Negeri 1 Rindingallo, tahun ajaran 2016/2017 yang berjumlah 26 siswa. Sampel dipilih dengan teknik random sampling atau sampel acak. Setiap subjek diberi hak yang sama pula untuk dipilih menjadi sampel. Instrumen yang digunakan adalah tes karangan terpimpin. Data yang sudah diperoleh berupa karangan terpimpin selanjutnya akan diolah, dianalisis, dan kemudian diidentifikasi kesalahan dengan menggunakan teknik persentase.

\section{HASIL DAN PEMBAHASAN}

Hasil penelitian menunjukkan bahwa frekuensi kesalahan deiksis yang dilakukan oleh siswa sebanyak 115 kesalahan. Kesalahan-kesalahan tersebut terdiri dari 
kesalahan penggunaan deiksis persona, temporal, dan lokasional. Dari ketiga klasifikasi kesalahan tersebut, kesalahan penggunaan deiksis persona berada pada kategori tinggi sekali, yaitu 97 kesalahan dengan persentase $84,35 \%$ dari keseluruhan kesalahan deiksis yang dibuat siswa. Selanjutnya, kesalahan deiksis temporal berada pada kategori hampir tidak ada kesalahan, yakni sebanyak 3 kesalahan dengan persentase 2,61\%. Kemudian, kesalahan penggunaan deiksis lokasional memiliki persentase 13,04\% kategori kurang sekali dengan frekuensi kesalahan sebanyak 15 kesalahan dari 115 kesalahan.

Hasil penelitian menunjukkan bahwa frekuensi kesalahan deiksis persona dalam karangan sederhana bahasa Jerman siswa berjumlah 97 kesalahan. Kesalahan pada Possesivepronomen kasus Nominativ merupakan kesalahan yang paling banyak muncul dalam karangan siswa dengan frekuensi $44(45,36 \%)$ kesalahan dari total kesalahan deiksis persona (97) dengan kategori tinggi. Penggunaan Personalpronomen pada kasus Nominativ sebanyak $36(37,11 \%)$ kesalahan dengan kategori cukup; Possesivepronomen kasus Akkusativ dengan sebanyak kesalahan 10 $(10,31 \%)$ dengan kategori hamper tidak ada kesalahan; dan Personalpronomen pada kasus Akkusativ memiliki frekuensi kesalahan $7(7,22)$ dengan kategori hampir tidak ada kesalahan.

\section{Kesalahan Penggunaan Deiksis Persona}

Berdasarkan hasil analisis data (Tabel 2 hal. 93), tingkat kesalahan siswa terhadap penggunaan deiksis persona berada pada kategori tinggi sekali dengan frekuensi kesalahan sebanyak 97 kesalahann dengan persentase $84,35 \%$. Kesalahan-kesalahan tersebut terdiri atas kesalahan dalam penggunaan Personalpronomen kasus Nominativ dan Akkusativ; dan penggunaan Possesivepronomen kasus Nominativ dan Akkusativ.

\section{a. Kesalahan Penggunaan Deiksis Persona (Personalpronomen) pada Kasus Nominativ \\ Berdasarkan hasil pengolahan data} penelitian, kesalahan dalam menggunakan Personalpronomen kasus Nominativ berjumlah 36 kesalahan atau 37,11\% (Tabel 3 hal. 94). Kesalahan ini terjadi disebabkan karena siswa masih kesulitan membedakan penggunaan Personalpronomen dan Possesivepronomen pada kasus Nominativ dengan kasus Akkusativ dalam bahasa Jerman. Tidak hanya menggunakan kata ganti diri pada penggunaan

Kesalahan penggunaan kata ganti diri pada kasus Nominativ dapat dilihat pada contoh berikut:

a) Er ist Ahmad. Er ist 17 Jahre alt. Ahmad ist wohnen in Solo.

Dia adalah Ahmad. Dia berumur 17 tahun. Ahmad tinggal di Solo.

b) Er ist Ahmad. Er ist 17 Jahre alt. Er wohnst in Solo.

Pada kalimat (a) di atas dapat diterima. Namun, ditinjau dari penggunaan kata ganti diri masih terdengar membosankan bagi pendengar atau pembaca jika mengucapkan nama orang atau nama benda berulang-ulang. Oleh karena itu, agar terdengar tidak monotan, maka seharusnya digunakan kata ganti diri terhadap nama orang atau benda.

Berdasarkan kalimat (a) di atas, seharusnya nama Ahmad pada kalimat ketiga ditulis menjadi er sebagai kata ganti diri terhadap orang ketiga tunggal. Dengan demikian, kalimat tersebut akan terdengar 
tidak monotan seperti yang dituliskan pada kalimat (b) di atas.

Kesalahan yang sama pada kalimat di atas juga dapat dilihat pada contoh kalimat berikut:

a) Sie heißt Vivin. Vivin wohnt in Berlin mit ihr eltern und zwei schwester und drei Bruder. Vivin ist schön.

Dia bernama Vivin. Vivin tinggal di Berlin bersama orang tua, dua saudara perempuannya, dan tiga saudara lakilakinya. Vivin sangat cantik.

b) Sie heißt Vivin. Sie wohnt in Berlin mit ihren Eltern und zwei Schwestern und drei Brüder. Sie ist schön.

Pada kalimat (a), siswa tidak menggunakan kata ganti diri yang referen terhadap nama 'Vivin' sebagai orang ketiga tunggal jenis feminin pada kalimat-kalimat berikutnya, sehingga terdengar monoton. Dengan kata lain, bahwa siswa seharusnya menggunakan kata ganti sie 'dia perempuan' untuk menggantikan nama 'Vivin' yang notabene berlaku sebagai orang keriga tunggal jenis feminin seperti yang dituliskan pada kalimat (b).

\section{b. Kesalahan Penggunaan Deiksis}

Persona Personalpronomen pada Kasus Akkusativ

Kesalahan deiksis persona

Possesivpronomen kasus Akkusativ dalam karangan sederhana siswa kelas XI SMAN 1 Rindingallo dapat dilihat pada kalimat berikut:

a) Ahmad begleitet ihr (die Schwestern) zu Schule jede morgen.

Ahmad mengantar mereka ke sekolah setiap hari.

b) Ahmad begleitet sie zur Schule jeden Morgen.

Kesalahan pada kalimat (a) di atas ditandai dengan adanya kata ganti $i h r$ yang referennya tidak tepat. Siswa menuliskan kata ganti $i h r$ dengan rujukan kata terhadap saudara perempuan (jamak) dari Ahmad. Namun sesungguhnya, kata ganti ihr tidak terdapat dalam Personalpronomen kasus Akkusativ. Oleh karena itu, Personalpronomen kasus Akkusativ yang tepat dalam kalimat (a) di atas adalah sie. Di mana kata ganti tersebut merujuk kepada persona yang lebih dari dua (die Schwestern). Dengan demikian, kata ganti referen kasus Akkusativ yang tepat adalah seperti pada kalimat (b).

\section{c. Kesalahan Penggunaan Deiksis Persona Possesivepronomen pada kasus Nominativ}

Kesalahan deiksis persona yang dilakukan oleh siswa pada kata ganti kepunyaan (Possesivepronomen) kasus Nominativ dapat dilihat pada kalimat berikut:

a) Er schwester ist schwestern in die Grundschule besuchen.

Saudara perempuannya bersekolah di sekolah dasar.

b) Seine Schwestern besuchen in die Grundschule.

Secara komunikatif, kedua contoh kalimat (a) dan (b) di atas dapat diterima. Namun, secara gramatik dianggap menyimpang dari tata bahasa Jerman. Kata yang digarisbawahi pada kalimat (a) di atas merupakan dua contoh kesalahan siswa dalam penggunaan Possesivepronomen kasus Nominativ. Siswa masih sulit membedakan penggunaan Personalpronomen dengan Possesivepronomen.

Pada kalimat (a), siswa salah mengonversi bentuk kata ganti diri er menjadi kata ganti kepunyaan dari er, yakni sein. Kata ganti kepunyaan tersebut digunakan untuk menjelaskan kepemilikan terhadap kata ganti er. Oleh karena itu, siswa 
seharusnya menulis seine Schwester seperti pada kalimat (b).

\section{d. Kesalahan Penggunaan Deiksis \\ Persona Possesivepronomen pada kasus Nominativ}

Kesalahan deiksis persona yang dilakukan oleh siswa pada kata ganti kepunyaan (Possesivepronomen) kasus Akkusativ dapat dilihat pada kalimat berikut:

a) Einmal im Jahr besucht ihre oma und $\underline{i h r}$ opa jahrlich besuchen in malang.

Sekali dalam setahun dia (Ahmad) mengunjungi oma dan opanya di Malang.

b) Einmal pro Jahr besucht er seine Oma und seinen Opa jahrlich nach Malang.

Kalimat (a) di atas tentu dinyatakan salah karena siswa menggunakan kata ganti kepunyaan yang tidak tepat terhadap subjek er (Ahmad). Dalam kalimat tersebut siswa menggunakan kata ganti kepunyaan $i h r$ pada frasa ihr Oma und ihr Opa dengan maksud kata ganti tersebut merujuk kepada er. Sedangkan sesungguhnya dalam tata bahasa Jerman, kata ganti kepunyaan yang tepat terhadap kata ganti er adalah sein bukanlah $i h r$. Kata ganti kepunyaan $i h r(e)$ digunakan pada kata ganti personal sie 'dia perempuan', sie 'mereka', dan Sie 'Anda'.

Penggunaan kata ganti kepunyaan pada kasus Akkusativ berbeda-beda tiap kata benda yang mengikutinya. Perbedaan itu ditandai dengan adanya deklinasi pada artikel atau kata ganti kepunyaan yang ditentukan berdasarkan jenis kata benda (maskulin, feminin, neutral, dan plural). Misal, kata ganti kepunyaan sein (dari er) diikuti jenis kata benda maskulin pada kasus Akkusativ seperti kata benda der Opa, maka artikel sein mendapat penambahan akhiran (Endung) - en menjadi seinen Opa. Selain itu, jikalau digunakan pada kata benda jenis feminin pada kasus Akkusativ seperti kata benda die Oma, maka artikel sein mendapat penambahan Endung -e pada artikel sein menjadi seine Oma. Dengan demikian, penggunaan kata ganti kepunyaan yang referannya tepat pada er adalah sein(en) seperti yang dituliskan pada kalimat (b) di atas.

\section{Kesalahan Penggunaan Deiksis Temporal (Waktu)}

Pada penelitian ini hanya ditemukan dua kesalahan deiksis temporal. Salah satu contoh kalimat deiksis temporal yang salah tersebut dapat dilihat di bawah ini:

a) Er sein zwei schwestern noch in Grundschule Rindingallo. Er gestern gehen dort hin fün besuchen.

Dia mempunyai dua saudara perempuan yang masih bersekolah di Sekolah Dasar Rindingallo. Tahun lalu, dia juga bersekolah di sana.

b) Er hat zwei Schwestern noch in die Rindingallo-Grundschule. Letztes Jahr besucht er auch dort hin.

Kesalahan deiksis temporal pada kalimat (a) di atas terletak pada pemilihan kata 'gestern' yang kurang tepat. Siswa menggunakan kata tersebut untuk menjelaskan bahwa er pernah bersekolah di sekolah itu. Jika dimaknai secara luas, makna gestern pada kalimat (a) berarti tahun lalu untuk menjelaskan bahwa er pernah bersekolah di sana. Oleh karena itu, siswa seharusnya menggunakan keterangan waktu 'tahun lalu' (letztes Jahr) seperti pada kalimat (b).

Berdasarkan hasil pengolahan data ditemukan bahwa, frekuensi kesalahan penggunaan deiksis temporal dalam karangan siswa kelas XI IPA 2 SMAN 1 Rindingallo adalah 3 kesalahan $(2,61 \%)$ dari total kesalahan penggunaan deiksis (115). 
Frekuensi tersebut berada pada kategori hampir tidak ada kesalahan. Hal demikian dikarenakan rata-rata siswa sudah mampu menggunakan kata-kata yang referen terhadap keterangan waktu.

\section{Kesalahan Deiksis Lokasional (Tempat)}

Beberapa contoh kalimat kesalahan deiksis lokasional dalam karangan siswa, antara lain:

a) Das ist sehr schön dort hin.

Di sana sangat indah.

b) Das ist sehr schön dort.

Pada kalimat (a) terjadi kesalahan deiksis lokasional. Kata referen dorthin digunakan sebagai kata penunjuk tempat dengan subjek masih dalam kegiatan melakukan. Sedangkan, kata dort digunakan untuk menunjuk tempat yang jauh dari si pembicara atau penulis. Oleh karena itu, kata penunjuk tempat yang tepat pada kalimat (a) di atas adalah dort seperti yang dituliskan pada kalimat (b) di atas.

Kesalahan yang sama juga dapat dilihat pada kalimat berikut:

a) Er ist Sein Vater aine polizist hier hin.

Ayah dia adalah seorang polisi di sini.

b) Sein Vater ist eine Polizist hier.

Kesalahan deiksis lokasional pada kalimat (a) ditandai dengan penggunaan hier hin yang kurang tepat dalam kalimat tersebut. Hier hin digunakan untuk menunjukkan tempat yang dekat dari pembicara atau si penulis. Selain hier hin, salah satu kata penunjuk tempat yang dekat dari si pembicara adalah hier. Namun, kedua penunjuk tempat tersebut tentu memiliki fungsi yang berbeda. Hier hin digunakan untuk menyatakan bahwa orang yang dibicarakan masih dalam kegiatan melakukan atau mendekati ke posisi si pembicara atau penulis. Sedangkan, hier digunakan untuk menyatakan bahwa si pembicara sedang bersama dengan orang yang diajak berbicara atau yang dibicarakan. Oleh karena itu, kata penunjuk tempat yang tepat pada kalimat (a) di atas bukan hier hin melainkan hier. Siswa belum mampu membedakan penggunaan dort, dort hin, da, dan da hin. Da dan da hin memiliki makna yang sama dengan dort dan dort hin, yakni 'di sana' dan 'di sini'.

\section{KESIMPULAN}

Kesalahan penggunaan deiksis pada karangan sederhana bahasa Jerman siswa kelas XI IPA 2 SMAN 1 Rindingallo terdiri dari kesalahan deiksis persona, deiksis temporal (waktu), dan deiksis lokasional (tempat) dengan jumlah kesalahan sebanyak 115 kesalahan. Kesalahan-kesalahan tersebut terdiri dari kesalahan penggunaan deiksis persona, temporal, dan lokasional. Dari ketiga klasifikasi kesalahan tersebut, kesalahan penggunaan deiksis persona berada pada kategori tinggi sekali, yaitu 97 kesalahan dengan persentase $84,35 \%$ dari keseluruhan kesalahan deiksis yang dibuat siswa. Selanjutnya, kesalahan penggunaan deiksis temporal berada pada kategori hampir tidak ada kesalahan, yakni sebanyak 3 kesalahan dengan persentase 2,61\%. Kemudian, kesalahan deiksis lokasional memiliki persentase 13,04\% kategori kurang sekali dengan frekuensi kesalahan sebanyak 15 kesalahan dari 115 kesalahan.

Kesalahan-kesalahan tersebut disebabkan oleh beberapa faktor, antara lain, siswa masih kerap dipengaruhi tata bahasa Indonesia yang tentu jauh berbeda dengan tata bahasa Jerman; kurangnya pemahaman yang baik oleh siswa terhadap penggunaan deiksis persona, baik Personalpronomen maupun Possesivpronomen, masing-masing dengan kasus Nominativ dan Akkusativ. 
Namun, dibandingkan dengan frekuensi kesalahan penggunaan deiksis persona, frekuensi kesalahan penggunaan deiksis temporal dan lokasional lebih sedikit. Hal tersebut dikarenakan sebagian besar siswa sudah mampu menggunakan kata-kata yang referen terhadap keterangan waktu dan tempat dengan baik, meskipun masih terdapat beberapa kesalahan yang terdapat dalam karangan sederhana siswa.

\section{DAFTAR PUSTAKA}

Afifah, Lilis; Widodo, Pratomo. 2015. Kesalahan Deiksis dalam Karangan Mahasiswa pada Niveau A2 di Jurusan Sastra Jerman UM. Malang: Jurnal UM.

Jufri, J. 2007. Metode Penelitian Bahasa. Sastra dan Budaya.

Jufri, J., 2017. Strategi Pembelajaran Bahasa Kasebae, Nurfadilla M. P. 2013. [Jurnal]: Deiksis dalam Bahasa Inggris dan Bahasa Banggai. Manado: Fakultas Sastra Universitas Sam Ratulangi.

Mantasiah, R., Juffri, J., \& Yusri, Y. 2017. Keefektifan Model Pembelajaran Jaring Laba-Laba (Webbed) dalam Keterampilan Menulis Karangan Sederhana Bahasa Jerman. INSANI, 20(2).

Qalbi, U. N., Mantasiah, R., Jufri, J., \& Yusri, Y. 2017. Efektivitas Model Pembelajaran Kooperatif Tipe Teams Games Tournaments dalam Keterampilan Menulis Bahasa Jerman Siswa Kelas XII IPA SMA Negeri 1 Bontonompo Kabupaten Gowa. INSANI, 20(1).

Romadloni, A., \& Mantasiah, R. Intercultural approach in foreign language learning to improve students' motivation. Senior Editors, 61.

Syamsurizal. 2015. Deiksis dalam Bahasa Pekal di Kabupaten Bengkulu Utara. [Jurnal]. Bengkulu: Jurnal Kantor Bahasa Provinsi Bengkulu.

Yusri, Y., Mantasiah, R., \& Jufri, J. 2018. The Use Of Two Stay Two Stray Model in English Teaching to Increase Student's Learning Outcome. Journal Of Advanced English Studies, 1(1), 39-43. 